\title{
Feeding behavior and responses in grazing lactating cows supplemented with peanut cake
}

\author{
Emellinne Ingrid de Sousa Costa', Gleidson Giordano Pinto de Carvalho², Aureliano José \\ Vieira Pires ${ }^{3}$, Carina Anunciação dos Santos Dias ${ }^{4}$, Weiler Giacomazza Cerutti ${ }^{5}$, Ronaldo Lopes \\ Oliveira² $^{2}$, Analívia Martins Barbosa², Camila Maida de Albuquerque Maranhão²
}

\author{
${ }^{1}$ Universidade Federal da Bahia, Programa de Pós-graduação em Zootecnia, Salvador, BA, Brasil. \\ ${ }^{2}$ Universidade Federal da Bahia, Escola de Medicina Veterinária e Zootecnia, Salvador, BA, Brasil. \\ ${ }^{3}$ Universidade Estadual do Sudoeste da Bahia, Departamento de Tecnologia Rural e Animal, Itapetinga, BA, Brasil. \\ ${ }^{4}$ Universidade Estadual de Santa Cruz, Programa de Pós-graduação em Ciência Animal, Itabuna, BA, Brasil. \\ ${ }^{5}$ Universidade Estadual do Oeste do Paraná, Programa de Pós-graduação em Zootecnia, Marechal Cândido Rondon, PR, Brasil
}

\begin{abstract}
This experiment was conducted to study the substitution of soybean meal with peanut cake in the supplement by assessing the feeding behavior and the interaction between the thermal environment and the physiological responses of eight crossbred cows with an average live weight of $500 \mathrm{~kg}$. Cows were divided into two $4 \times 4$ Latin squares and managed on pasture. The peanut cake was included at the levels of $0,330,660$, and $1,000 \mathrm{~g} \mathrm{~kg}^{-1}$ in the supplement as a replacement for soybean meal. The feeding behavior variables were not affected by the levels of peanut cake. No differences were found for the physiological parameters of the animals with the replacement of soybean meal for peanut cake in the supplements. Peanut cake can replace up to $100 \%$ soybean meal in the supplement of grazing lactating crossbred cows without altering the feeding behavior or physiological parameters of the animals.
\end{abstract}

Key Words: biodiesel, idleness, pasture, respiratory rate, ruminants

\section{Introduction}

The Brazilian milk production increased by $4.5 \%$ from 2010 to 2011, reaching a total of 32.091 billion liters of milk. The effectiveness of milked cows increased by $1.3 \%$ and the national average milk yield also rose compared with 2010, with 1,382 liters/cow/year (IBGE, 2011).

The pasture-based milk production system has been linked to aspects regarding the reduction of production costs and when rationally conducted makes the dairy business competitive, since it elevates the availability of forage and provides a more efficient use of the dairy herd.

Tropical pastures are potentially able to provide the production of up to $13.5 \mathrm{~kg}$ of milk/cow/day without supplementation (Deresz et al., 1994). According to Deresz and Mozzer (1994), it is possible to maintain the dairy herd on pasture during the year in most regions of Brazil, supplementing only in the period of forage scarcity. However, the forage supply varies during the year due to different pasture growth rates. An efficient bulk feeding should ensure that the nutritional requirements of the herd

Received September 27, 2014 and accepted February 6, 2015 Corresponding author: gleidsongiordano@yahoo.com.br http://dx.doi.org/10.1590/S1806-92902015000400002

Copyright $(\subset 2015$ Sociedade Brasileira de Zootecnia. This is an Open Access article distributed under the terms of the Creative Commons Attribution Non-Commercial License, which permits unrestricted non-commercial use, distribution, and reproduction in any medium, provided the original work is properly cited. are met primarily by the pasture during the year, within the conditions of economic profitability.

With the effect caused by climatic seasonality, the use of alternative feeds in these periods is essential, which may include residues and by-products from the agro- or biofuel industries, complementing the feeding of animals during the off-season. During this period the prices of traditional feed concentrates with corn and soybean meal tend to increase. Among the oilseeds used for biofuel production, the peanut has excelled because of its oil content, wherein $50 \%$ can be extracted for the production of the fuel. The peanut cake is a by-product of this process resulting from mechanical extraction of the oil, which, according to Abdalla et al. (2008), contains average values of $43 \%$ crude protein and $8.5 \%$ ether extract.

The number of studies on the ingestive behavior of ruminants has increased considerably due to their relevance in the interpretation of the effects found in many other studies (Santana Jr. et al., 2012). According to Welch (1982), the feeding behavior of an animal varies according to the characteristics of the feed, as a resource to maintain feed intake and its productive potential. This makes it important to assess the feeding and rumination behavior to discover its implications on the daily feed intake, and additionally provide information on the interaction between diet and animal, which are essential to predict the likely effects of supplementation on feed intake of lactating cows on pasture (Dado and Allen, 1994). 
In this sense, this study was conducted to evaluate the effect of replacing soybean meal for peanut cake in diets for lactating dairy cows on pasture and its implications on their feeding behavior.

\section{Material and Methods}

The experiment was conducted in the municipality of São Gonçalo dos Campos, BA, Brazil, from July to September 2011. The experimental site is characterized by average annual temperature of $26^{\circ} \mathrm{C}, 85 \%$ relative humidity, and annual rainfall of approximately $1,200 \mathrm{~mm}$.

Eight Gir $\times$ Holstein crossbred lactating multiparous cows with a LW of $500 \mathrm{~kg}$, between the 60th and 90th days of lactation and with a milk yield of $15 \mathrm{~kg} / \mathrm{day}$, were used for the experiments. The experimental period was 60 days divided into four periods of 15 days, in which 11 days were used for adaptation and four days for collection. The cows were divided into two simultaneous $4 \times 4$ Latin squares. The animals were housed in ten paddocks with Tanzania grass (Panicum maximum cv. Tanzânia), with an area of 0.8 ha each, delimited by a electric fence with a rotational stocking system with three days of occupation and 27 days of rest. All paddocks had shaded areas with water and mineral supplementation ad libitum. The pasture was managed in a variable stocking system, and whenever necessary regulator animals were used to adjust the supply forage to provide $8 \%$ of the live weight on a dry matter (DM) basis.

Twenty changes of paddocks were made throughout the experiment, determined by the previously established support and grazing pressure. To ensure the intended forage provision, forage availability in the pasture was monitored according to the methodology described by McMeniman (1997). This material was weighted and the values were recorded to calculate its availability for animal consumption.

The feeds used as ingredients in the supplement were peanut cake (Arachis hypogaea), soybean meal, and ground corn (Table 1). The peanut cake was included at the levels of $0,330,660$, and $1,000 \mathrm{~g} \mathrm{~kg}^{-1}$ in substitution of soybean meal, formulated according to the NRC (2001) to be isonitrogenous $(18 \% \mathrm{CP})$. The supplement was supplied in the amount of $3.0 \mathrm{~kg}$ per day during the 15 days of each experimental period, twice daily, at $06.00 \mathrm{~h}$ and at $15.00 \mathrm{~h}$, during milking.

Concentrations of dry matter (DM), ash, organic matter $(\mathrm{OM})$, crude protein $(\mathrm{CP})$, ether extract (EE) and lignin (Table 2) were obtained according to the methodology described by the AOAC (1990). Neutral detergent fiber (NDF) and acid detergent fiber (ADF) were determined according to the methodology described by Mertens (2002).

The corrections of NDF and ADF for ash and protein were performed according to Detmann et al. (2012). The percentage of total carbohydrates (TC) was obtained by the equation of Sniffen et al. (1992), and non-fiber carbohydrates according to Detmann and Valadares Filho (2010).

Indigestible neutral detergent fiber (iNDF) was used as an internal marker to evaluate the dry matter intake, obtained after ruminal incubation for $240 \mathrm{~h}$ (Casali et al., 2008).

Intake estimates were obtained according to Detmann et al. (2001). The animals were weighed before each experimental period to adjust the stocking rate and forage supply and to estimate DM intake based on body weight.

The feeding behavior assessments were performed on the 10th day of each experimental period before the morning milking, when the animals were marked with paint for easy identification from a distance. The assessments were performed in all experimental periods, during $24 \mathrm{~h}$, at

Table 1 - Chemical composition of the ingredients

\begin{tabular}{|c|c|c|c|c|}
\hline \multirow[b]{2}{*}{ Nutrient } & \multirow[b]{2}{*}{ Forage } & \multicolumn{3}{|c|}{ Feedstuff } \\
\hline & & Maize & Soybean meal & Peanut cake \\
\hline Dry matter & 266.4 & 881.2 & 885.3 & 909.4 \\
\hline $\operatorname{Ash}^{1}$ & 88.1 & 13.8 & 65.3 & 52.0 \\
\hline Crude protein ${ }^{1}$ & 116.3 & 50.1 & 483.6 & 446.5 \\
\hline Ether extract ${ }^{1}$ & 17.8 & 46.9 & 20.9 & 185.3 \\
\hline NDFap $^{1}$ & 590.1 & 106.5 & 112.2 & 118.3 \\
\hline Cellulose $^{1}$ & 315.6 & 40.4 & 88.5 & 79.9 \\
\hline Hemicellulose $^{1}$ & 265.5 & 77.9 & 52.1 & 52.2 \\
\hline Total carbohydrates ${ }^{1}$ & 777.8 & 889.2 & 430.2 & 316.2 \\
\hline Non-fiber carbohydrates ${ }^{1}$ & 128.5 & 757.5 & 276.9 & 154.6 \\
\hline Fiber carbohydrates ${ }^{1}$ & 649.3 & 131.7 & 153.3 & 161.6 \\
\hline
\end{tabular}

NDFap - neutral detergent fiber corrected for ash and protein.

${ }^{1} \mathrm{~g} \mathrm{~kg}^{-1}$ of the dry matter. 
five-minute intervals, by visual observation. After milking, the animals remained in the waiting corral until completing all the process, then returning to the paddock with the other animals that were not part of the experiment. At each interval the activities of grazing, rumination, idleness and permanence at the trough were recorded, and the behavioral variables occurring during the $24 \mathrm{~h}$ of evaluation were calculated based on these data. The time spent to consume the supplement during milking sessions corresponded to the time spent at the trough.

On the subsequent day, the number of chews was counted and the rumination time of each ruminal bolus was assessed per animal, using a digital timer. The total chewing time was determined according to methodology described by Polli et al. (1996). The feed (FE) and rumination efficiencies (RUE) of DM and NDF and the total chewing time (TCT, in/day) were calculated according to the methodology described by Burger et al. (2000).

The variables grams of DM and NDF per meal were obtained by dividing the average individual intake of each fraction by the number of grazing and trough periods per day during $24 \mathrm{~h}$. Feed and rumination efficiencies expressed in $\mathrm{g} / \mathrm{h}$ of DM and NDF were obtained as the average daily intake of DM and NDF divided by the total time spent feeding and the total time spent ruminating, respectively, during $24 \mathrm{~h}$. The variables grams of DM and NDF per bolus were obtained by dividing the average individual intake of each fraction by the number of boli ruminated during $24 \mathrm{~h}$. Discretization of the time series was performed directly on data collection spreadsheets, as described by Silva et al. (2006). The average duration of each of the discrete periods was obtained by dividing the daily times for each of the activities by the number of discrete periods. In all behavioral variables, an animal represented one experimental unit.

During all data collection periods, the environment was monitored daily by the weather station at the experimental farm and by an alcohol thermometer inserted in a small plastic globe, painted black (black globe), and placed at the mean height of the animal body (Table 3 ). The black globes with thermometers were maintained on the pasture exposed

Table 2 - Centesimal composition of the ingredients and chemical composition of the experimental diets

\begin{tabular}{|c|c|c|c|c|c|}
\hline \multirow[b]{2}{*}{ Item $\left(\mathrm{g} \mathrm{kg}^{-1} \mathrm{DM}\right)$} & \multirow[b]{2}{*}{ Forage } & \multicolumn{4}{|c|}{ Peanut cake level ( $\left.\mathrm{g} \mathrm{kg}^{-1} \mathrm{DM}\right)$} \\
\hline & & 0 & 330 & 660 & 1000 \\
\hline \multicolumn{6}{|c|}{ Centesimal composition } \\
\hline Soybean meal & - & 320.5 & 214.7 & 108.9 & - \\
\hline Peanut cake & - & - & 111.1 & 222.2 & 336.5 \\
\hline Vitamin-mineral mix (Top Milk Núcleo) & - & 22.6 & 22.6 & 22.5 & 22.5 \\
\hline Organic matter ${ }^{1}$ & 911.9 & 810.0 & 813.9 & 818.0 & 822.1 \\
\hline $\mathrm{Ash}^{1}$ & 88.1 & 52.6 & 51.4 & 50.1 & 48.8 \\
\hline Crude protein ${ }^{1}$ & 116.3 & 187.9 & 186.1 & 184.3 & 182.4 \\
\hline Ether extract ${ }^{1}$ & 17.8 & 37.5 & 55.6 & 73.8 & 92.4 \\
\hline Indigestible neutral detergent fiber ${ }^{1}$ & 24.14 & 4.98 & 5.01 & 5.03 & 5.06 \\
\hline NDFap $^{1}$ & 590.1 & 105.9 & 106.6 & 107.3 & 108.1 \\
\hline Cellulose ${ }^{1}$ & 315.6 & 54.9 & 54.2 & 53.5 & 52.8 \\
\hline Hemicellulose $^{1}$ & 265.5 & 67.8 & 67.8 & 67.6 & 67.5 \\
\hline Fibrous carbohydrates ${ }^{1}$ & 649.3 & 135.6 & 136.7 & 137.7 & 138.8 \\
\hline Non-fiber carbohydrates ${ }^{1}$ & 128.5 & 586.4 & 570.2 & 554.1 & 537.6 \\
\hline Total carbohydrates ${ }^{1}$ & 777.8 & 722.0 & 706.9 & 691.8 & 676.4 \\
\hline
\end{tabular}

DM - dry matter; NDFap - neutral detergent fiber corrected for ash and protein.

${ }^{1} \mathrm{~g} \mathrm{~kg}^{-1}$ dry matter.

${ }^{2} \mathrm{~g} \mathrm{~kg}^{-1}$ crude protein

Table 3 - Mean values of black globe temperature, air temperature, relative humidity and black globe temperature index

\begin{tabular}{lcccccccc}
\hline Climate variables & BGTm & BGTp & BGTs & AT & RH, \% & BGTIm & BGTIp & BGTI \\
\hline Mean & 23.60 & 29.09 & 25.91 & 26.33 & 68.59 & 72.33 & 70.59 & 67.41 \\
\hline
\end{tabular}

BGTm - black globe temperature in the milking parlor; BGTp - black globe temperature in the paddock; BGTs - black globe temperature in natural shade; AT - air temperature; $\mathrm{RH}$ - relative humidity; BGTIm - black globe temperature in the milking parlor; BGTIp - black globe temperature in the paddock; BGTIs - black globe temperature in natural shade. 
to direct sunlight, protected from direct sunlight (shade tree) and in the milking parlor. Air temperature, relative humidity, and black globe temperatures were recorded during the last four days of each experimental period, every hour, for $12 \mathrm{~h} /$ day, beginning at $06.00 \mathrm{~h}$ and ending at $18.00 \mathrm{~h}$. From the obtained data, the thermal comfort index was calculated based on the black globe temperature and humidity index (BGTHI), according to the formula developed by Buffington et al. (1981).

Rectal temperature, respiratory rate, and heart rate were evaluated after milking in the last four days of each experimental period. Rectal temperature was measured using a digital thermometer inserted into the rectum of the animal until the buzzer sounded indicating temperature stability. The respiratory rate was measured on each animal by counting the movements of the flank for $15 \mathrm{~s}$ and multiplying the number of movements by four to obtain the corresponding value per minute. Heart rate was obtained with a stethoscope and the number of heartbeats per 15 $\mathrm{s}$ was recorded, and the result was multiplied by four to obtain the number of beats per minute.

The results regarding the effect of the peanut cake levels on feeding behavior and physiological variables were interpreted by analysis of variance and regression analysis, using the System for Statistical and Genetic Analyses (SAEG), at 5\% probability.

\section{Results and Discussion}

There was no difference $(\mathrm{P}>0.05)$ for the feeding behavior variables as a function of the peanut cake levels (Table 4). The results for grazing time (494 min, on average), were lower than those found by Silva et al. (2004), who evaluated the feeding behavior of $3 / 4$ Holstein $\times$ Zebu heifers on Brachiaria decumbens pasture with levels of supplementation in the trough and found grazing times varying between 10.35 and $11.03 \mathrm{~h}$. The lower values found in the present study are due to the fact that animals remained in the waiting corral after milking, awaiting completion of the milking time for all animals.

The idle time was not influenced $(\mathrm{P}>0.05)$ by the levels of peanut cake, averaging $351.56 \mathrm{~min}$. This finding differs from that found by Patiño Pardo et al. (2003), who, in observations of the diurnal feeding behavior of steers on pasture subjected to supplementation levels, noted a linear increase in relation to the supplementation level.

The lack of significant effect on the idle activity can be explained by the similarity of physical and chemical properties of diets with similar NDF. The time results are in agreement with the cattle feeding behavior pattern, confirming the responses obtained by several authors (Pinto et al., 2010; Pinheiro et al., 2012).

The animals consumed on average $11.798 \mathrm{~kg}$ of DM and $6.449 \mathrm{~kg}$ of NDF. This statement is also supported by Carvalho (2002), who worked with levels of NDF in the diet of lactating goats and observed a linear increase in the time spent feeding as the level of fiber in the diets also increased.

The NDF contents of up to $10 \%$ in the diet contributed to the lack of effect of the inclusion of the peanut cake on DM and NDF intakes, confirming the results of Mertens (1997), who reported that the fiber content is inversely related to the net energy content, and when the NDF content of the diet is elevated there is increased energy expenditure for feeding, so that the animal may meet its energy requirements.

In this work, the feeding time was shorter than that described by Correia et al. (2012), who studied Zebu steers

Table 4 - Feeding behavior and efficiency of dairy cows supplemented with peanut cake

\begin{tabular}{|c|c|c|c|c|c|c|c|}
\hline \multirow[b]{2}{*}{ Item } & \multicolumn{4}{|c|}{$\begin{array}{c}\text { Peanut cake level } \\
\left(\mathrm{g} \mathrm{kg}^{-1} \mathrm{DM} \text { in the supplement) }\right.\end{array}$} & \multirow[b]{2}{*}{ SEM } & \multicolumn{2}{|c|}{ Significance } \\
\hline & 0 & 330 & 660 & 1000 & & $\mathrm{~L}$ & Q \\
\hline \multicolumn{8}{|c|}{ Behavior $(\min )$} \\
\hline GRAZING & 493.13 & 495.00 & 497.50 & 491.88 & 1.22 & 0.992 & 0.849 \\
\hline RUM & 575.00 & 542.50 & 560.63 & 528.12 & 10.26 & 0.210 & 0.992 \\
\hline IDLE & 326.25 & 359.38 & 340.00 & 380.63 & 11.83 & 0.096 & 0.841 \\
\hline TROUGH & 45.63 & 43.12 & 41.87 & 39.37 & 1.30 & 0.216 & 0.992 \\
\hline \multicolumn{8}{|c|}{ Intake $(\mathrm{g})$} \\
\hline DM/day & 12700.43 & 11578.29 & 11736.42 & 11177.07 & 323.00 & 0.156 & 0.677 \\
\hline NDF/day & 7056.90 & 6296.68 & 6407.02 & 6036.35 & 216.94 & 0.143 & 0.657 \\
\hline FE g DM/h & 1460.40 & 1295.43 & 1359.70 & 1271.71 & 42.17 & 0.160 & 0.624 \\
\hline $\mathrm{FE} g \mathrm{NDF} / \mathrm{h}$ & 811.14 & 703.56 & 744.75 & 686.56 & 27.716 & 0.136 & 0.613 \\
\hline \multicolumn{8}{|c|}{ Intake $(\min )$} \\
\hline kg DM & 43.05 & 48.01 & 47.37 & 48.52 & 1.25 & 0.174 & 0.455 \\
\hline $\mathrm{kg} \mathrm{NDF}$ & 78.13 & 89.26 & 87.62 & 90.81 & 2.85 & 0.145 & 0.467 \\
\hline
\end{tabular}

SEM - standard error of the mean; L - linear effect; Q - quadratic effect; RUM - rumination; TROUGH - remaining at the trough; FE - feed efficiency; ns - not significant. 
fed diets with peanut cake replacing soybean meal in the concentrate and observed a feeding time of $330 \mathrm{~min} /$ day. The result was attributed to the concentrate fraction, which corresponded to $35 \%$ of the diet, whereas in the present study it corresponded to $60 \%$ of the total diet.

There was no difference $(\mathrm{P}>0.05)$ between the feed and rumination efficiencies in $\mathrm{g} \mathrm{DM} / \mathrm{h}$ and $\mathrm{g} \mathrm{NDF} / \mathrm{h}$ in response to the levels of peanut cake in the supplement (Table 5). It was also observed that rumination in $\mathrm{min} / \mathrm{kg} \mathrm{DM}$ and $\mathrm{min} / \mathrm{kg}$ NDF and chewing in min/kg DM and min/kg NDF were not influenced by the levels of peanut cake in the supplement, which contradicts the findings of Carvalho et al. (2011), in which the intake of nutrients had implications in the time spent on feeding activities and idle time. The feed and rumination efficiencies are affected primarily by the animal intake, which could affect the time spent on activities of feeding, rumination, and idleness. In the present study, the similarity in the feed and rumination efficiencies is possibly due to the absence of a significant effect of the grazing and rumination activities on the levels of peanut cake (Carvalho et al., 2008).

Although the levels of EE in the concentrates with peanut cake varied from 3.75 to 9.24 , respectively, for diets with 0 and $100 \%$ cake in the total diet, when considering forage intake, the values were close to $3 \%$ of EE, therefore not interfering with the rumination activity. It is known that diets with high levels of EE may affect feed intake by reducing the fiber digestion and the passage rate of the digesta through the gastrointestinal tract (NRC, 2001), which was not observed in the present study.
The chewing activity is one of the most commonly used measures for evaluating the effectiveness of the fiber, due to the effects on salivary secretion, the feed crushing process, rumen functioning, and dry matter intake (Colenbrander et al., 1991). For the number of chews per bolus and chewing time per bolus, as well as the number of boli ruminated per day, and the total chewing time, no differences were observed $(\mathrm{P}>0.05)$ with the replacement of soybean meal for peanut cake in the supplement. As shown in Table 4, there was no difference in dry matter intake (DMI) and therefore the chewing time was not affected, corroborating Cardoso et al. (2006), who stated that chewing time is directly related to DMI and the concentration of neutral detergent fiber (NDF) in the diet.

The number of ruminated boli and the chewing time per bolus are associated with the proportion of concentrate, the NDF, and the physical form of diet (Mendes et al., 2015). Thus, diets with higher levels of concentrate usually cause a reduction in the number and average time for each bolus to be ruminated, due to the lower NDF content.

For the discretization of the time series, the periods of grazing, remaining at the trough, rumination, and idle ( $\mathrm{n} /$ day) as well as the time spent per period in grazing, remaining at the trough, ruminating, and idle ( $\mathrm{min} /$ period) did not change with the levels of peanut cake in the diet (Table 6). The average number of periods spent at the trough was 3.40, with no difference between the levels of peanut cake in the supplement.

The values found in the present study for the discretization of the time series were similar to those found

Table 5 - Mean values of time spent in activities related to rumination by cows supplemented with peanut cake

\begin{tabular}{|c|c|c|c|c|c|c|c|}
\hline \multirow[b]{2}{*}{ Item } & \multicolumn{4}{|c|}{$\begin{array}{c}\text { Peanut cake level } \\
\left.\text { ( } \mathrm{g} \mathrm{kg}^{-1} \mathrm{DM} \text { in the supplement }\right)\end{array}$} & \multirow[b]{2}{*}{ SEM } & \multicolumn{2}{|c|}{ Significance } \\
\hline & 0 & 330 & 660 & 1000 & & $\mathrm{~L}$ & Q \\
\hline $\mathrm{gDM} / \mathrm{h}$ & 1376.69 & 1300.03 & 1265.26 & 1271.72 & 25.56 & 0.441 & 0.676 \\
\hline $\mathrm{gNDF} / \mathrm{h}$ & 766.96 & 705.77 & 688.27 & 685.18 & 19.02 & 0.355 & 0.640 \\
\hline \multicolumn{8}{|c|}{ Chewing activity } \\
\hline $\mathrm{NRB} /$ day & 642.01 & 577.68 & 621.99 & 586.82 & 15.05 & 0.404 & 0.657 \\
\hline $\mathrm{CRB} /$ day & 33071.49 & 30254.63 & 33042.83 & 31247.56 & 695.90 & 0.586 & 0.657 \\
\hline TCT h/day & 18.562 & 18.01 & 18.34 & 17.65 & 0.20 & 0.096 & 0.841 \\
\hline \multicolumn{8}{|c|}{ Rumination (min/kg) } \\
\hline kg DM & 46.91 & 48.62 & 47.69 & 47.83 & 0.35 & 0.874 & 0.518 \\
\hline
\end{tabular}

SEM - standard error of the mean; L - linear effect; Q - quadratic effect; NC - average number of chews; CT - average chewing time; NRB - number of ruminated boli; CRB - number of chews per ruminated bolus; TCT - total chewing time; ns - not significant. 
by Silva et al. (2005), who worked with grazing crossbred heifers and obtained an average of 3.8. The values were obtained by observing the feeding behavior during milking twice a day, wherein this was the time the animals remained at the trough.

Although no difference was detected for the time per period at the trough, it is believed that the chemical composition of the diets and their acceptability by the animals may have resulted in a relatively shorter time (12.96 min) when compared with grazing cows in other studies (Silva et al., 2005; Abreu Filho et al., 2009), showing values greater than $15 \mathrm{~min}$. This fact was explained by the permanence of the animals at the trough during milking, because they received the supplement during this time. This is in agreement with Silva et al. (2005), who stated the preference of the animals to seek food in the trough at the time it is supplied, and that when receiving the concentrate these animals tend to consume it quickly in short periods at the trough, which was observed in the present study.

It was also observed that the amount $(\mathrm{kg})$ of $\mathrm{DM}$ and NDF per feeding period were not influenced by the inclusion of peanut cake in the diet, which may be due to the absence of significant effects on the DM and NDF intakes (Table 4) and the number of feeding periods (Table 6).
The levels of peanut cake had no effects $(\mathrm{P}>0.05)$ on heart rate, respiratory rate, rectal temperature and body surface temperature (Table 7).

The heart rate of the animals remained similar among the evaluated diets, with an average of 76.63 (beats $/ \mathrm{min}$ ), not exceeding the reference values for cattle, which, according to Detweiler (1988), varies between 48-80 bpm (beats per minute). Silva and Starling (2003) emphasized the importance of respiratory stabilization; high respiratory rates over a long period of time can cause a reduction in blood pressure of $\mathrm{CO}_{2}$, in addition to increasing the heat accumulated in the tissues due to rapid work of respiratory muscles. The reduction in blood pressure is responsible for the increased heart rate in an attempt to maintain blood pressure at the physiological level considered normal.

The respiratory rate showed a mean value of 36.38 mov/min, which is within the range recommended by Hahn and Mades (1997), who stated that the normal respiratory frequency rate for adult dairy cattle of the Holstein breed is between 10 to 60 flank movements per minute. This indicates either absence of animals with heat stress or that heat stress was minimal.

Rectal temperature and body surface temperature indicate that the animals remained within the normal range for cattle (Detweiler, 1988; Hahn \& Mades, 1997).

Table 6 - Mean values of discrete periods relative to feeding behavior

\begin{tabular}{|c|c|c|c|c|c|c|c|}
\hline \multirow[b]{2}{*}{ Item } & \multicolumn{4}{|c|}{$\begin{array}{c}\text { Peanut cake level } \\
\text { ( } \mathrm{g} \mathrm{kg}^{-1} \mathrm{DM} \text { in the supplement) }\end{array}$} & \multirow[b]{2}{*}{ SEM } & \multicolumn{2}{|c|}{ Significance } \\
\hline & 0 & 330 & 660 & 1000 & & $\mathrm{~L}$ & Q \\
\hline \multicolumn{8}{|c|}{ Number of periods (n/day) } \\
\hline GRAZING & 8.87 & 8.75 & 9.00 & 8.50 & 0.11 & 0.739 & 0.750 \\
\hline RUM & 15.12 & 14.87 & 15.25 & 14.00 & 0.28 & 0.363 & 0.498 \\
\hline IDLE & 18.75 & 18.87 & 18.62 & 18.75 & 0.05 & 0.957 & 0.992 \\
\hline TROUGH & 3.75 & 3.25 & 3.25 & 3.37 & 0.12 & 0.485 & 0.382 \\
\hline \multicolumn{8}{|c|}{ Time per period (min) } \\
\hline GRAZING & 62.88 & 67.70 & 69.38 & 68.69 & 1.47 & 0.272 & 0.470 \\
\hline RUM & 39.16 & 39.29 & 37.80 & 40.10 & 0.48 & & \\
\hline IDLE & 18.45 & 19.53 & 18.77 & 22.95 & 1.27 & 0.068 & 0.312 \\
\hline TROUGH & 12.48 & 13.23 & 13.75 & 12.39 & 0.32 & 0.957 & 0.293 \\
\hline \multicolumn{8}{|c|}{ Intake per meal } \\
\hline kg DM & 1.57 & 1.64 & 1.65 & 1.58 & 0.03 & 0.267 & 0.651 \\
\hline $\mathrm{kg}$ NDF & 0.86 & 0.89 & 0.90 & 0.81 & 0.02 & 0.711 & 0.988 \\
\hline
\end{tabular}

SEM - standard error of the mean; L - linear effect; Q - quadratic effect; RUM - rumination, TROUGH - remaining at the trough; ns - not significant.

Table 7 - Mean values of heart rate, respiratory rate, rectal temperature and body surface temperature in cows supplemented with peanut cake

\begin{tabular}{|c|c|c|c|c|c|c|c|}
\hline \multirow[b]{2}{*}{ Item } & \multicolumn{4}{|c|}{$\begin{array}{c}\text { Peanut cake level } \\
\text { ( } \mathrm{g} \mathrm{kg}^{-1} \mathrm{DM} \text { in the supplement) }\end{array}$} & \multirow[b]{2}{*}{ SEM } & \multicolumn{2}{|c|}{ Significance } \\
\hline & 0 & 330 & 660 & 1000 & & $\mathrm{~L}$ & Q \\
\hline Respiratory rate (mov/min) & 34.82 & 36.43 & 37.07 & 37.19 & 0.4432 & 0.063 & 0.401 \\
\hline Rectal temperature $\left({ }^{\circ} \mathrm{C}\right)$ & 37.99 & 38.02 & 38.05 & 38.07 & 0.0628 & 0.634 & 0.975 \\
\hline Body surface temperature $\left({ }^{\circ} \mathrm{C}\right)$ & 30.77 & 31.98 & 30.97 & 30.52 & 0.1703 & 0.584 & 0.275 \\
\hline
\end{tabular}

SEM - standard error of the mean; L - linear effect, Q - quadratic effect; beats/min - heartbeats in a minute; mov/min - flanking movements in a minute; ns - not significant. 
The high temperatures associated with high relative humidity affect the rectal temperature and respiratory rate, and may cause stress (Baêta and Souza, 1997). Because of the high temperatures of tropical regions, animals tend to reduce activities that generate heat to maintain the body temperature, preferring thus to remain idle (Miotto, 2008). However, as shown in Table 7, we can observe that the animals remained within their thermal comfort zone.

\section{Conclusions}

Peanut cake originating from biodiesel production can replace up to $100 \%$ of soybean meal in supplements for grazing lactating crossbred cows without altering their feeding behavior or negatively influencing their physiological parameters.

\section{References}

Abdalla, A. L.; Silva Filho, J. C.; Godoi, A. R.; Carmo, C. A. and Eduardo J. L. P. 2008. Utilização de subprodutos da indústria de biodiesel na alimentação de ruminantes. Revista Brasileira de Zootecnia 37(supl. especial):260-258.

Abreu Filho, G.; Cardoso, E. O.; Silva, G. M. and Silva, R. R. 2009. Aspectos metodológicos dos períodos discretos no comportamento ingestivo de novilhos a pasto. In: Anais do 4 Congresso Internacional Boi de Capim. Salvador, BA.

Baeta, F. C. and Souza, C. F. 1997. Ambiência em edificações rurais: conforto animal. Universidade Federal de Viçosa, Viçosa, MG.

Buffington, D. E.; Collazo-Arocho, A.; Canton, G. H. and Pitt, D. 1981. Black globehumidity index (BGHI) as comfort equation for dairy cows. Transactions of the ASAE 3:711-713.

Bürger, P. J.; Pereira, J. C.; Queiroz, A. C.; Silva, J. F. C.; Valadares Filho, S. C.; Cecon, P. R. and Casali, A. D. P. 2000. Comportamento ingestivo em bezerros holandeses alimentados com dietas contendo diferentes níveis de concentrado Revista Brasileira de Zootecnia 29:236-242.

Cardoso, A. R.; Carvalho, S.; Galvani, D. B.; Pires, C. C.; Gasparin, B. G. and Garcia, R. P. A. 2006. Comportamento ingestivo de cordeiros alimentados com dietas contendo diferentes níveis de fibra em detergente neutro. Ciência Rural 36:604-609.

Carvalho, G. G. P. 2008. Cana-de-açúcar tratada com óxido de cálcio em dietas para ovinos, caprinos, novilhas e vacas em lactação. Tese (D.Sc.). Universidade Federal de Viçosa, Viçosa, MG.

Carvalho, G. G. P.; Garcia, R.; Pires, A. J. V.; Detmann, E.; Ribeiro, L. S. O.; Chagas, D. M. T.; Silva, R. R. and Pinho, B. D. 2011. Comportamento ingestivo em caprinos alimentados com dietas contendo cana-de-açúcar tratada com óxido de cálcio. Revista Brasileira de Zootecnia 40:1767-1773.

Carvalho, S. 2002. Decomposição e comportamento ingestivo de cabras em lactação alimentadas com dietas contendo diferentes níveis de fibra. Tese (D.Sc.). Universidade Federal de Viçosa, Viçosa MG.

Casali, A. O.; Detmann, E.; Valadares Filho, S. C.; Pereira, J. C.; Henriques, L. T.; Freitas, S. G. and Paulino, M. F. 2008. Influência do tempo de incubação e do tamanho de partículas sobre os teores de compostos indigestíveis em alimentos e fezes bovinas obtidos por procedimentos in situ. Revista Brasileira de Zootecnia 37:335-342.
Colenbrander, V. F.; Noller, C. H. and Grant, R. J. 1991. Effect of fiber content and particle size of alfafa silage on perfomance and chewing behaviour. Journal of Dairy Science 74:2681-2690.

Correia, B. R.; Oliveira, R. L.; Jaeger, S. M. P. L.; Bagaldo, A. R.; Carvalho, G. G. P.; Oliveira, G. J. C.; Lima, F. H. S. and Oliveira, P. A. 2012. Comportamento ingestivo e parâmetros fisiológicos de novilhos alimentados com tortas do biodiesel. Archivos de Zootecnia 61:79-89.

Dado, R. G. and Allen, M. S. 1994. Variation in and relationships among feeding, chewing, and drinking variables for lating dairy cows. Journal of Dairy Science 77:132-144.

Deresz, F.; Cózer, A. C.; Martins, C. E.; Botrel, M. A.; Aroeira, L. J. M.; Vasquez, H. M. and Matos, L. L. 1994. Utilização do capimelefante (Pennisetum purpureum Schum.) para produção de leite. p.183-199. In: Anais do Simpósio Brasileiro de Forrageiras e Pastagens. CBNA, Campinas.

Deresz, F. and Matos, L. L. 1996. Influência do período de descanso da pastagem de capim-elefante na produção de leite de vacas mestiças Holandês x Zebu. p.166-167. In: Anais da 33a Reunião Anual da Sociedade Brasileira de Zootecnia. Sociedade Brasileira de Zootecnia, Fortaleza.

Deresz, F. and Mozzer, O. L. 1994. Produção de leite em pastagem de capim-elefante. p.195-215. In: Capim-elefante: produção e utilização. Carvalho, M. M.; Alvim, M. J.; Xavier, D. F. and Carvalho, L. A., eds. EMBRAPA-CNPGL, Coronel Pacheco.

Detmann, E. and Valadares Filho, S. C. 2010. On the estimation of non-fibrous carbohydrates in feeds and diets. Arquivo Brasileiro de Medicina Veterinária e Zootecnia 62:980-984.

Detmann, E.; Paulino, M. F.; Zervoudakis, J. T.; Valadares Filho, S. C.; Euclydes, R. F.; Lana, R. P. and Queiroz, D. S. 2001. Cromo e indicadores internos na determinação do consumo de novilhos mestiços, suplementados, a pasto. Revista Brasileira de Zootecnia 30:1600-1609.

Detmann, E.; Valadares Filho, S. C.; Gionbelli, M. P.; Paulino, P. V. R. and Paulino, M. F. 2012. Uso de técnicas de regressão na avaliação, em bovinos de corte, da eficiência de conversão do alimento em produto: comparação entre grupos experimentais. Revista Brasileira de Zootecnia 41:138-146.

Detweiler, D. R. 1988. Regulação cardíaca. p.113-143. In: Fisiologia dos animais domésticos. 10.ed. Dukes, H. H. and Swendson, M. J., eds. Guanabara Koogan, Rio de Janeiro.

Hahn, G. L. and Mades, T. L. 1997. Heat waves in relation to thermoregulation, feeding behaviour and mortality of feedlot cattle. In: Proceedings of the 5th International Livestock Environmental Symposium, St. Joseph. American Society of Agricultural Engineering, St. Joseph.

IBGE - Instituto Brasileiro de Geografia e Estatística. 2011. Produção da pecuária municipal. Rio de Janeiro. v.39, p.1-63.

McMeniman, N. P. 1997. Methods of estimating intake of grazing animals. p.133-168. In: Anais da 34a Reunião Anual da Sociedade Brasileira de Zootecnia; Simpósio sobre Tópicos Especiais em Zootecnia. Sociedade Brasileira de Zootecnia, Juiz de Fora.

Mendes, F. B. L.; Silva, R. R.; Carvalho, G. G. P.; Silva, F. F.; Lins, T. O. J.; Silva, A. L. N.; Macedo, V.; Abreu Filho, G. A.; Souza, S. O. and Guimarães. 2015. Ingestive behavior of grazing steers fed increasing levels of concentrate supplementation with different crude protein contents. Tropical Animal Health and Production 47:423-428.

Mertens, D. R. 1997. Creating a system for meeting the fiber requirements of dairy cows. Journal of Dairy Science 80:1463-1481.

Mertens, D. R. 2002. Gravimetric determination of amylase-treated neutral detergent fiber in feeds with refluxing in beaker or crucibles: Collaborative study. Journal of AOAC International 85:1217-1240.

Miotto, F. R. C. 2008. Consumo alimentar, desempenho produtivo e aspectos comportamentais de tourinhos Nelore $\mathrm{x}$ Limousin 
alimentados com dietas contendo gérmen de milho integral. Dissertação (M.Sc.). Universidade Federal do Tocantins, Araguaína.

NRC - National Research Council. 2001. Nutrient requirements of dairy cattle. 7th ed. National Academic of Sciences, Washington.

Patiño Pardo, N. M.; Fischer, V.; Balbinotti, M.; Moreno, C. B.; Ferreira, E. X.; Vinhas, R. I. and Monks, P. L. 2003. Comportamento ingestivo diurno de novilhos em pastejo submetidos a níveis crescentes de suplementação energética. Revista Brasileira de Zootecnia 32:1408-1418.

Pinheiro, A. A.; Veloso, C. M.; Rocha Neto, A. L.; Silva, R. R.; Silva, F. F.; Mendes, F. B. L.; Santana Júnior, H. A.; Azevedo, S. T. and Carvalho, G. G. P. 2012. Comportamento ingestivo de novilhas leiteiras alimentadas com níveis de farelo de cacau (Theobromacacao) na dieta. Revista Brasileira de Saúde e Produção Animal 13:224-236.

Pinto, A. P.; Marques, J. A.; Abrahão, J. J. S.; Nascimento, W. G.; Costa, M. A. T. and Lugão, S. M. B. 2010. Comportamento e eficiência ingestiva de tourinhos mestiços confinados com três dietas diferentes. Archivos de Zootecnia 59:427-434.

Polli, V. A.; Restle, J.; Senna, D. B. and Almeida, S. R. S. 1996. Aspectos relativos à ruminação de bovinos e bubalinos em regime de confinamento. Revista da Sociedade Brasileira de Zootecnia 25:987-993.

Santana Júnior, H. A.; Silva, R. R.; Carvalho, G. G. P.; Silva, F. F.; Mendes, F. B. L.; Abreu Filho, G.; Trindade Júnior, G.; Cardoso,
E. O.; Barroso, D. S. and Pereira, M. M. 2012. Correlação entre digestibilidade e comportamento ingestivo de novilhas suplementadas a pasto. Archivos Zootecnia 61:549-558.

Silva, R. G. and Starling, J. M. C. 2003. Evaporação cutânea e respiratória em ovinos sob altas temperaturas ambientes. Revista Brasileira de Zootecnia 32:1956-1961.

Silva, R. R.; Carvalho, G. G. P.; Magalhães, A. F.; Pires, A. J. V.; Franco, I. L.; Silva, F. F.; Veloso, C. M.; Bonomo, P. and Pinheiro, A. A. 2004. Comportamento ingestivo de novilhas recebendo diferentes níveis de suplementação em pastejo. Aspectos comportamentais. p.1-3. In: Proceedings of the 2nd Grassland Ecophysiology and Grazing Ecology. Curitiba.

Silva, R. R.; Carvalho, G. G. P.; Magalhães, A. F.; Silva, F. F.; Prado, I. N.; Franco, I. L.; Veloso, C. M.; Chaves, M. A. and Panizza, J. C. J. 2005. Comportamento ingestivo de novilhas mestiças holandês em pastejo. Archivos de Zootecnia 54:63-74.

Silva, R. R.; Silva, F. F.; Prado, I. N.; Carvalho, G. G. P. and Franco, I. L. 2006. Comportamento ingestivo de bovinos. Aspectos metodológicos. Archivos de Zootecnia 55:293-296.

Sniffen, C. J.; O'Connor, J. D.; Van Soest, P. J.; Fox, D. G. and Russell, J. B. 1992. A net carbohydrate and protein system for evaluating cattle diets: II. Carbohydrate and protein availability. Journal of Animal Science 70:3562-3577.

Welch, J. G. 1982. Rumination, particle size and passage from the rumen. Journal of Animal Science 54:885-894. 